\title{
Will GST Make India an Economic Union? Respect to Kolhapur Industrial Area
}

\author{
Mr. Amar S. Patil \\ M. Phil. Research Scholar, \\ Chhatrapati Shahu Institute of Business Education and Research, Kolhapur, Maharashtra, India
}

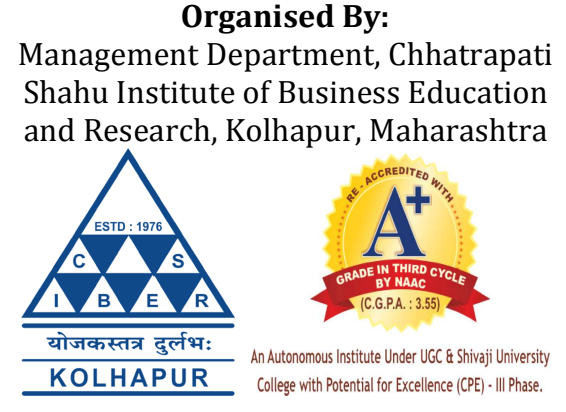

How to cite this paper: Mr. Amar S. Patil "Will GST Make India an Economic Union? Respect to Kolhapur Industrial Area" Published in International Journal of Trend in Scientific Research and Development (ijtsrd), ISSN: 2456-6470, Special Issue | Fostering Innovation, Integration and Inclusion Through Interdisciplinary Practices in Management, March 2019, pp.11-16, URL: https://www.ijtsrd.c om/papers/ijtsrd23 051.pdf

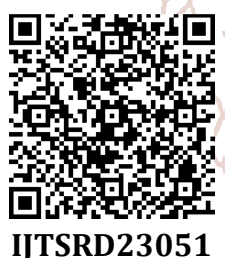

\section{INTRODUCTION}

Since ancient age to today's technology driven world, one thing remain constant that is change. Every business organization experienced a change in its structure, competition, process, operations and more of its other aspects. As a result those businesses are survived who make them flexible with change and adjust with new environment.

In our country every business had to follow the rules of variety of taxes, varies with each state before implementation of Goods and Service Tax. There were more than 17 taxes and multiple cesses were subsumed into GST, aligning India with global regimes. Central taxes like excise duty, services tax, and state taxes - including value added tax, Octroi and purchase tax - were all rolled into one. The GST provided for free flow of tax credits and did away with cascading effect due to tax on tax. This was leading to boost financial condition of businesses and that is resulted in reduced prices of goods and services for consumers. It also ensured a single law for the whole country with uniform procedures and rules, which reduces compliance burden and business complexity. The government of India sacrificed for revenues, but improved compliance should cover any gap.

There are as many as six slabs, excluding exempt goods. Though most goods fall in the $12 \%, 18 \%$ and $28 \%$ brackets, there is a case for merging slabs to reduce complexity and classification disputes. The $12 \%$ and $18 \%$ bracket could be merged into one single slab in the $14-16 \%$ range.

\section{GST: A HISTORICAL PERSPECTIVE:}

1. In year 2005 the Kelkar Task Force on Fiscal Responsibility and Budget Management (FRBM) recommended to introduce a comprehensive tax in India by replacing Central and State VAT.

2. In 2007-08 budget Union Finance minister announced the effect that GST would be introduced with effect from April 1, 2010 and requested to prepare a road map for introduction of GST in India.

3. The representatives of the Department of Revenue of Union Finance Ministry prepared a model of GST in 
International Journal of Trend in Scientific Research and Development (IJTSRD) @ www.ijtsrd.com eISSN: 2456-6470

2008 to review the comments by Government of India. It was decided that a Committee of Principal Secretaries/Secretaries of Finance/Taxation and Commissioners of Trade Taxes of the States would be set up to consider these comments, and submit their views.

4. Due to lack of political consensus, the constitutional amendment bill lapsed in 2013.

5. The Bill was passed by the Rajya Sabha on 3rd August 2016 and by the Lok Sabha on 8th August 2016. The Constitutional amendment paved way for introduction of Goods and Services Tax in India.

6. GST was launched with effect from 1st July 2017 by Sh. Narendra Modi, Hon'ble Prime Minister of India in the presence of Sh. Pranab Mukherjee, the then President of India in a mid-night function at the Central Hall of Parliament of India.

\section{Benefits of GST-}

$>$ Removal of number of taxes

$>$ Removal of tax on tax called as removal of cascading effect.

$>$ Increase in the production of goods and services

$>$ Increase in the demand and supply of goods and services.

$>$ Due to lower burden of taxes, there is a reduction in overall costs.

$>$ Burden has been decreased on the final tax payer.

$>$ Control over the circulation of black money as the system normally followed by traders and shopkeepers will be put to a mandatory check.

$>$ Revenue of the government increased by extended tax base.

\section{Challenges of GST-}

$>$ Impact on pricing of goods and services due to subsumed taxes.

$>$ To keep a check on the rates of GST. If the rates of GST are over $15 \%$, then the goods would be costlier.

$>$ There are still a few states in India which lack for IT Infrastructure.

$>$ A separate law must be drafted.

$>$ Transfer of goods from one state to other all over the country. Continuation of specific exemptions on central GST and state GST.

$>$ Constitutional amendments to enable GST to central and state governments.

$>$ Constitutional amendments to enable levy of GST on imports.

\section{Literature Review-}

The Article on-"One year of GST: The successes, failures and what's next on the agenda" in Times of India -states the impact of goods and service tax on overall economic condition of the country. It said that the wide fear of rise in inflation rate as happened in one tax regime nations, which were not happened with India. GST creates a seamless national market by disappearing cheak posts at each state borders. After implementation of GST the businesses and consumers were came to single umbrella of one tax nationally.

Transparent digital processes and incentive of input tax credit and invoice matching encourage formalisation of economy by tax evasion stop making sense.
In Financial Express the article on" The myth of an ideal single-rate GST -by" Mukesh Butani and Tarun Jainexpressed the pros and cons of single tax rate over two or three tier tax structure. Fiscal impact and burden on common man leads to cancel the idea of single tax rate under GST. This article explains the benefits of two or three tier tax structure. The authorities began to occupy the attention on classification and rate disputes. Trimming the tax-slabs causes business woes on account of inverted duty structure to also diminish.

The Economic Times- Archit Gupta in his article on "Keeping it simple: Reconciliation of GST data" - to know the wrong or omitted data filed by business organisations, the GST council encountered the system of reconciliation. Under reconciliation matching of data filed by supplier with that of recipient for the specific period of time. Every tax payer has mandatorily required to file all the periodic GST returns. They should have to also find the mismatch and correct the entries in books of accounts.

One of the articles "Impact of GST on the Indian Economy" at Clear tax stated the short term impact of GST with a viewpoint on Consumers in June 2018. They explained that after implementation of GST compliance is increased to the small scale manufactures and traders. As an effect consumers are getting the products at slightly higher rate.

The article also explains long term benefits of GST, like Lowering tax rates as well as lower tax slabs, in which low tax rate for essential commodities and higher tax rates for luxuries goods. It is really expected that the revenue of government will increase and fiscal deficit of government comes under check.

Research by D C Agrawal and Ankur Kukreti on “GOOD OR EVIL: Understanding The Effect of GST on Indian Economy (with specific reference to Dehradun)" stated the pros and cons of GST for overall Indian economy. Researchers indentified some parameters that driving the economy of our country, and find out the impact on such parameters after implementation of GST in India. In this regards they explained about high compliance cost of GST implementation, GST related complexity, IT infrastructure required for GST, impact on government revenue, effect on tax evasion etc.

\section{Research Gap}

There is inconclusive amount of research articles on overall impact of GST on Indian economy is takes place. Through this paper researcher contributes for understanding the consequences of GST on small and medium scale businesses in Kolhapur.

\section{Problem statement}

To identify the impact of GST on main parameters that drives businesses.

\section{Objective -}

$>$ Objective of this paper is to review and analyse the impact of GST on the businesses.

$>$ This study also aims at identify the factors of impact and to understand the areas of improvement needed after implementation of GST. 
International Journal of Trend in Scientific Research and Development (IJTSRD) @ www.ijtsrd.com eISSN: 2456-6470

\section{Methodology}

The systematic random sample of 43 Units of businesses in Shivaji Udymnagar industrial area is selected for the study. This sample consists of manufacturer, traders, exporters, job worker and Service provider.

Based on the responses from respondents on closed ended self created questionnaire primary data is collected by the researcher.

Secondary data is collected from available literature.

\section{Tools Used}

To present and analysis of data in systematic manner the table, charts, graphs is used in this research.

\section{DATA ANALYSIS AND INTERPRETATION}

The study entitled "will GST make India an economic Union?with respect to Kolhapur industrial area."- looks into how GST have affected on working of business?, what are actual effects and the expectations of businesses from GST.

\section{Description of Sample}

In order to provide descriptive information about demographic variable frequency table is employed which revealed that 69.80 percent composed of males and $30.20 \%$ composed of females which is evident from pie chart-

\begin{tabular}{|c|c|c|c|}
\hline & Frequency & Percent & $\begin{array}{c}\text { Cumulative } \\
\text { Percent }\end{array}$ \\
\hline Male & 30 & $69.80 \%$ & 69.80 \\
\hline Female & 13 & $30.20 \%$ & 100.00 \\
\hline Total & 43 & 100 & \\
\hline
\end{tabular}
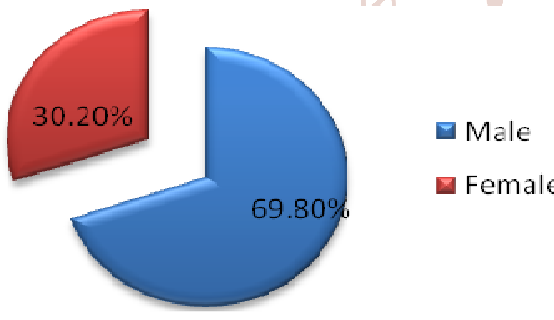

\section{Educational Background}

The population for research consist of $38 \%$ up to $12^{\text {th }}, 30 \%$ Graduates, 30\% Post Graduates and 2\% Certified Professional, as depicted in the table-

\begin{tabular}{|c|c|c|c|}
\hline & Frequency & Percent & $\begin{array}{c}\text { Cumulative } \\
\text { Percent }\end{array}$ \\
\hline Up to 12th & 16 & $38 \%$ & 38.00 \\
\hline Graduate & 13 & $30 \%$ & 68.00 \\
\hline Post Graduate & 13 & $30 \%$ & 98.00 \\
\hline $\begin{array}{c}\text { Certified } \\
\text { Professional }\end{array}$ & 1 & $2 \%$ & 100.00 \\
\hline Total & 43 & 100 & \\
\hline
\end{tabular}

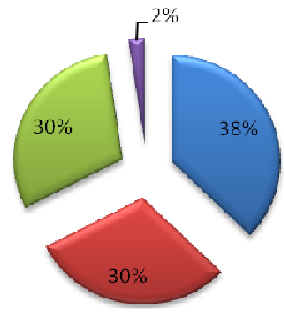

Up To 12 th

Graduate

प्ast Graduate

acertified Professional

\section{Nature /Scope of Business-}

The Sample of Businesses containing $23.3 \%$ are manufactures, $27.9 \%$ are the Traders, $11.6 \%$ are job workers, $25.6 \%$ are exporters And 11.6\% are service providers.

\begin{tabular}{|c|c|c|c|}
\hline & Frequency & Percent & $\begin{array}{c}\text { Cumulative } \\
\text { Percent }\end{array}$ \\
\hline Manufacturing & 10 & $23.3 \%$ & 23.3 \\
\hline $\begin{array}{c}\text { Trading \& Or } \\
\text { Dealer }\end{array}$ & 12 & $27.9 \%$ & 51.2 \\
\hline Job Work & 5 & $11.6 \%$ & 62.8 \\
\hline Exporter & 11 & $25.6 \%$ & 88.4 \\
\hline $\begin{array}{c}\text { Service } \\
\text { Provider }\end{array}$ & 5 & $11.6 \%$ & 100.00 \\
\hline Total & 43 & $100 \%$ & \\
\hline
\end{tabular}
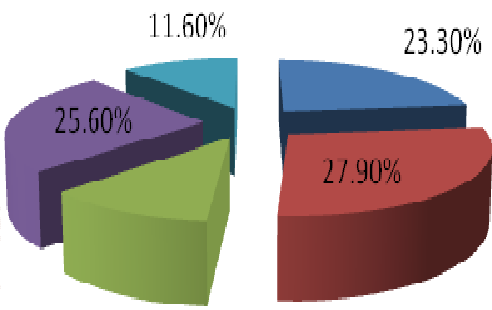

$11.60 \%$
Manufacturing

- Trading \& Or Dealer

JobWork

Exporter

Service Provider

\section{GST Returns Filed By-}

Under the GST law all businesses have to file returns, Businesses filing returns with the help of professional consultant are $34.9 \%$, businesses those who have allotted a specific person to file returns are $25.6 \%$, only $9.3 \%$ businesses filing GST returns himself, whereas 18.6\% businesses filing returns through their accountants.

\begin{tabular}{|c|c|c|c|}
\hline & Frequency & Percent & $\begin{array}{c}\text { Cumulative } \\
\text { Percent }\end{array}$ \\
\hline Self & 4 & $9.3 \%$ & 9.3 \\
\hline Accountant & 8 & $18.6 \%$ & 27.9 \\
\hline $\begin{array}{c}\text { Specific Person } \\
\text { Allotted }\end{array}$ & 11 & $25.6 \%$ & 53.5 \\
\hline $\begin{array}{c}\text { By Professional } \\
\text { Consultant }\end{array}$ & 15 & $34.9 \%$ & 88.4 \\
\hline Other & 5 & $11.6 \%$ & 100 \\
\hline Total & 43 & $100 \%$ & \\
\hline
\end{tabular}

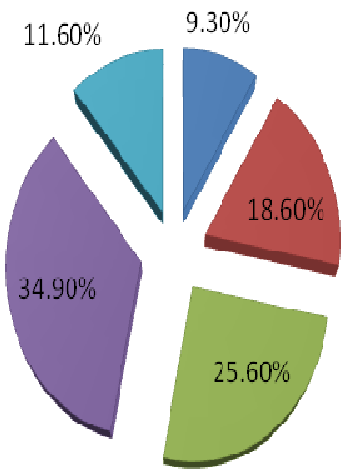

$\square$ Self

Accountant

口Specific Person Allotted

$\square$ By Professional Consultant cother

Businesses view about Registration, Filing returns and tax payments under GST- 
International Journal of Trend in Scientific Research and Development (IJTSRD) @ www.ijtsrd.com eISSN: 2456-6470

$41.9 \%$ businesses have satisfied with the simple, technology driven, effective common portal of GST. There are $23.2 \%$ businesses are expecting more simplification on same grounds of portal. There are less businesses are unsatisfied with GST common Portal

\begin{tabular}{|c|c|c|c|}
\hline & Frequency & Percent & $\begin{array}{c}\text { Cumulative } \\
\text { Percent }\end{array}$ \\
\hline $\begin{array}{c}\text { Satisfied with } \\
\text { Common } \\
\text { Portal }\end{array}$ & 18 & $41.9 \%$ & 41.9 \\
\hline $\begin{array}{c}\text { Unsatisfied } \\
\text { with } \\
\text { Common } \\
\text { Portal }\end{array}$ & 6 & $14 \%$ & 55.9 \\
\hline Neutral & 9 & $20.9 \%$ & 76.8 \\
\hline $\begin{array}{c}\text { Simplification } \\
\text { Required }\end{array}$ & 10 & $23.2 \%$ & 100 \\
\hline Total & 43 & $100 \%$ & \\
\hline
\end{tabular}

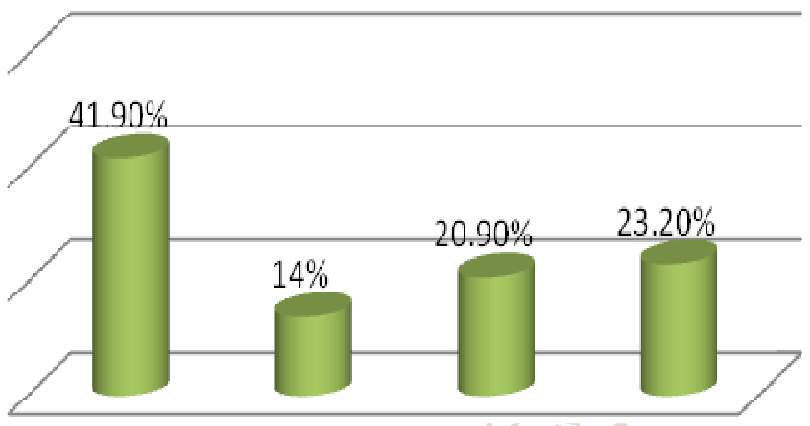

GST Promote "Make in India" campaign-

The businesses of Kolhapur saying GST is not promoting Make in India campaign are $30.2 \%$, The businesses who have taken benefits after GST implementation are $48.9 \%$.

\begin{tabular}{|c|c|c|c|}
\hline & Frequency & Percent & $\begin{array}{c}\text { Cumulative } \\
\text { Percent }\end{array}$ \\
\hline Yes & 21 & $48.9 \%$ & 48.9 \\
\hline No & 13 & $30.2 \%$ & 79.1 \\
\hline May Be & 9 & $20.9 \%$ & 100 \\
\hline Total & 43 & 100 & \\
\hline
\end{tabular}

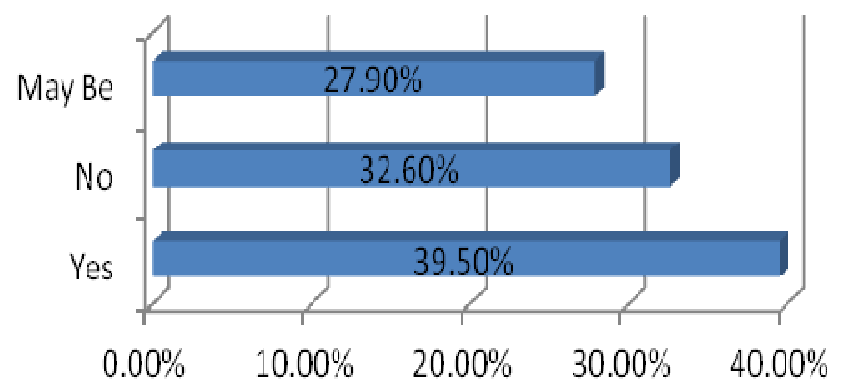

Competitiveness Of Indian Products In Global Market after GST

This is with immediate effect on export business that is grown after GST and competing in global marker have $39.5 \%$. There are $27.9 \%$ businesses in confusion of expression of interest about competitiveness of Indian products in global market. Also $32.6 \%$ businesses are defining that GST has no effect on competitiveness in global market.

\begin{tabular}{|c|c|c|c|}
\hline & Frequency & Percent & $\begin{array}{c}\text { Cumulative } \\
\text { Percent }\end{array}$ \\
\hline Yes & 17 & $39.5 \%$ & 39.5 \\
\hline No & 14 & $32.6 \%$ & 72.1 \\
\hline May Be & 12 & $27.9 \%$ & 100 \\
\hline Total & 43 & 100 & \\
\hline
\end{tabular}

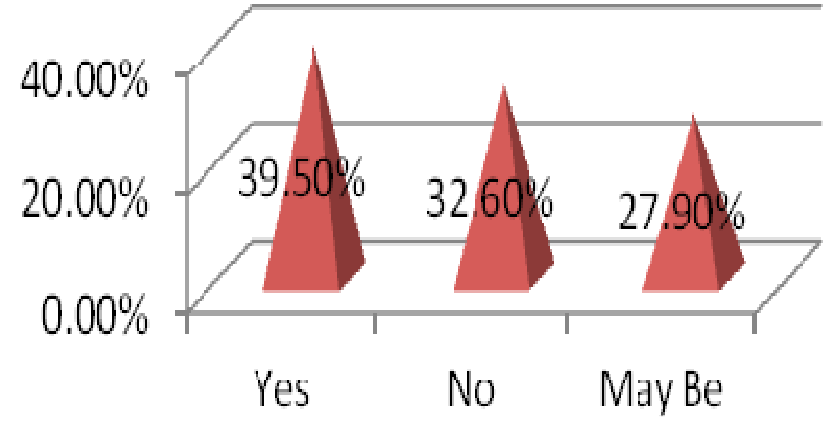

Expression on Tax Slab Structure (0, 5, 12, 18 And 28\%)The tax slab structure extended by GST Council is not effective to $39.5 \%$ because they are opposite to number of Tax rates. $30.2 \%$ businesses are in favour of GST tax slab.

\begin{tabular}{|c|c|c|c|}
\hline $\begin{array}{c}\text { Excellent } \\
\text { Structure }\end{array}$ & 6 & $14 \%$ & 14 \\
\hline Good & 13 & $30.2 \%$ & 44.2 \\
\hline $\begin{array}{c}\text { Not Good } \\
\begin{array}{c}\text { Single Tax } \\
\text { cienate } \\
\text { Expected }\end{array}\end{array}$ & 17 & $39.5 \%$ & 83.7 \\
\hline
\end{tabular}

Is GST plugged the government revenue leakages? Government revenue leakages are plugged by GST saying $39.5 \%$ businesses. $27.9 \%$ businesses saying GST may or may not affected on Government revenue leakages, And 14 businesses are saying GST has not plugged government revenue leakages.

\begin{tabular}{|c|c|c|c|}
\hline & Frequency & Percent & $\begin{array}{c}\text { Cumulative } \\
\text { Percent }\end{array}$ \\
\hline Yes & 17 & $39.5 \%$ & 39.5 \\
\hline No & 14 & $32.6 \%$ & 72.1 \\
\hline May Be & 12 & $27.9 \%$ & 100 \\
\hline Total & 43 & 100 & \\
\hline
\end{tabular}


International Journal of Trend in Scientific Research and Development (IJTSRD) @ www.ijtsrd.com eISSN: 2456-6470
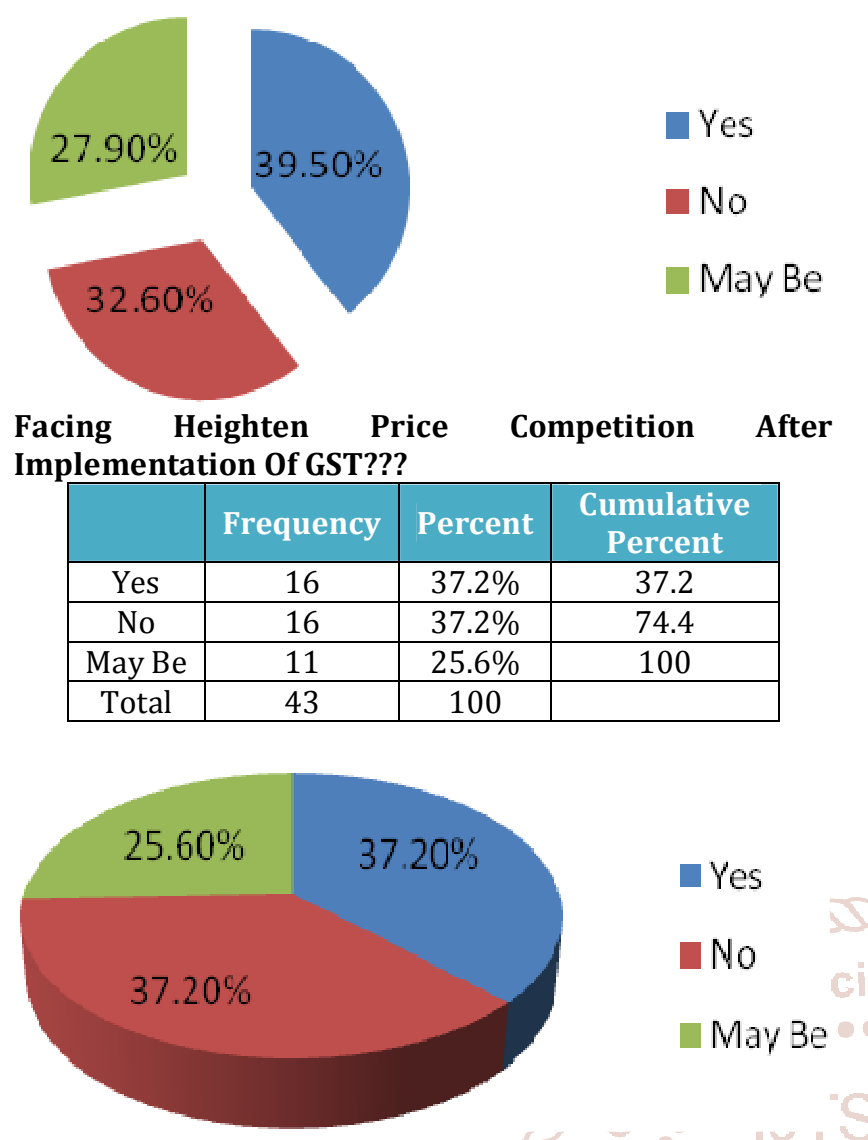

Business Achieved A Cost Reduction For Products? The businesses who have achieved cost reduction after GST are $37.9 \%$. The businesses who have faced cost increase are $34.9 \%$

\begin{tabular}{|c|c|c|c|}
\hline & Frequency & Percent & $\begin{array}{c}\text { Cumulative } \\
\text { Percent }\end{array}$ \\
\hline Yes & 16 & $37.2 \%$ & 37.2 \\
\hline No & 15 & $34.9 \%$ & 72.1 \\
\hline May Be & 12 & $27.9 \%$ & 100 \\
\hline Total & 43 & 100 & \\
\hline
\end{tabular}

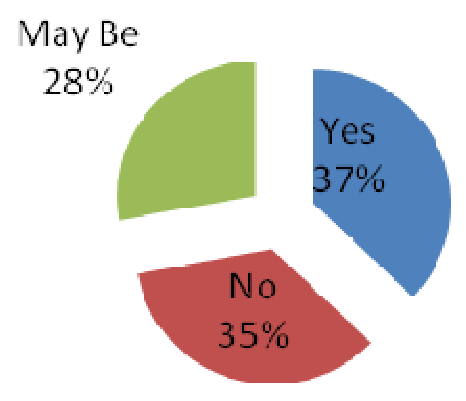

Change is required preferentially

\begin{tabular}{|c|c|c|c|}
\hline & Frequency & Percent & $\begin{array}{c}\text { Cumulative } \\
\text { Percent }\end{array}$ \\
\hline $\begin{array}{c}\text { GSTR 1 } \\
\text { Extension by 5 } \\
\text { Days }\end{array}$ & 6 & $14 \%$ & 14 \\
\hline $\begin{array}{c}\text { GSTR 1 } \\
\text { Extension by } \\
\text { 10 Days }\end{array}$ & 5 & $11.6 \%$ & 25.6 \\
\hline $\begin{array}{c}\text { GSTR 3B } \\
\text { Extension by 5 } \\
\text { Days }\end{array}$ & 12 & $27.9 \%$ & 53.5 \\
\hline
\end{tabular}

\begin{tabular}{|c|c|c|c|}
\hline $\begin{array}{c}\text { GSTR 3B } \\
\text { Extension by } \\
10 \text { Days }\end{array}$ & 12 & $27.9 \%$ & 81.4 \\
\hline $\begin{array}{c}\text { Removal of } \\
\text { Penalties }\end{array}$ & 8 & $18.6 \%$ & 100 \\
\hline Total & 43 & $100 \%$ & \\
\hline
\end{tabular}

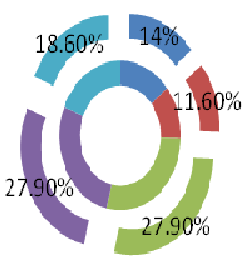

IGSTR 1 Extension by 5 Days

"GSTR 1 Extension by 10 Days

mGSTR 3B Extension by 5 Days

nGSTR 3B Extension by 10 Days

\section{DISCUSSION}

The result of the study show that-

1. The impact of GST on businesses is depending on kind of Business. The businesses that $\mathrm{m}$ favourable impacted are exporter and service providers, whereas the job working businesses i have negative impact on its system of working.

2. Because of common, technology driven and transparent GST return filing most of small and medium enterprises satisfied with common portal developed by GST.

3. 3. All the businesses are filing returns on monthly basis, it is observed that more businesses filing the monthly returns through professional consultants which increase in cost of business working. There is need to arrange the workshops on GST return Filing and payment of GST under same portal.

4. By removing cascading effect of tax and starting of single tax increases the competitiveness of Indian products in global market. The businesses are also expecting lower tax slab for growth of Indian exports, which is achieved by decreased cost of production.

5. The businesses are confused about tax slab structure that is $0 \%, 5 \%, 12 \%, 18 \%$ And $28 \%$, they are expecting less slabs with moderate percentage of GST will boost small and medium businesses in Kolhapur

6. On the grounds of government revenue leakages GST has achieved far more than VAT tax Structure.

7. As far as GST implementation is considered each and every business faced heighten price competition as GST removed all interstate trade barriers. India became a single market unlike state boundaries under VAT.

8. There are various businesses who have achieved reduction in cost after GST. As number of different taxes is removed and moderate single tax is imposed on business.

9. The common expectations of all businesses is to extend the monthly GSTR filing due dates by 5 days.

\section{CONCLUSION}

The purpose of this study is to present and analyse data gathered from respondents. The findings are presented and analysed in accordance with the research framework. The objective is to find out effects of GST on small and medium enterprise.

To go with the statement "only change is constant" -GST is implemented in entire country. By analysing pros and cons of GST, it is noted the GST has favourable impact on businesses as well as overall Indian economy. However it is 
International Journal of Trend in Scientific Research and Development (IJTSRD) @ www.ijtsrd.com eISSN: 2456-6470

essential to develop better and simpler GST return filing system and arranging the workshops to make each and every business self sufficient in GST return filing. Irrespective of these, businesses are motivated to perform well because they live in GST culture of India.

\section{REFERENCES-}

[1] https://cbec-gst.gov.in

[2] http://www.gstcouncil.gov.in

[3] https://www.gst.gov.in
[4] http://economictimes.indiatimes.com

[5] http://www.gstindiaexpert.com

[6] http://www.jaagore.com

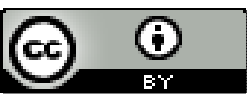

[7] http://www.fundsindia.com

Copyright (C) 2019 by author(s) and International Journal of Trend in Scientific Research and Development Journal. This is an Open Access article distributed under the terms of the Creative Commons Attribution License (CC BY 4.0) (http://creativecommons.org/licenses/by/4.0)

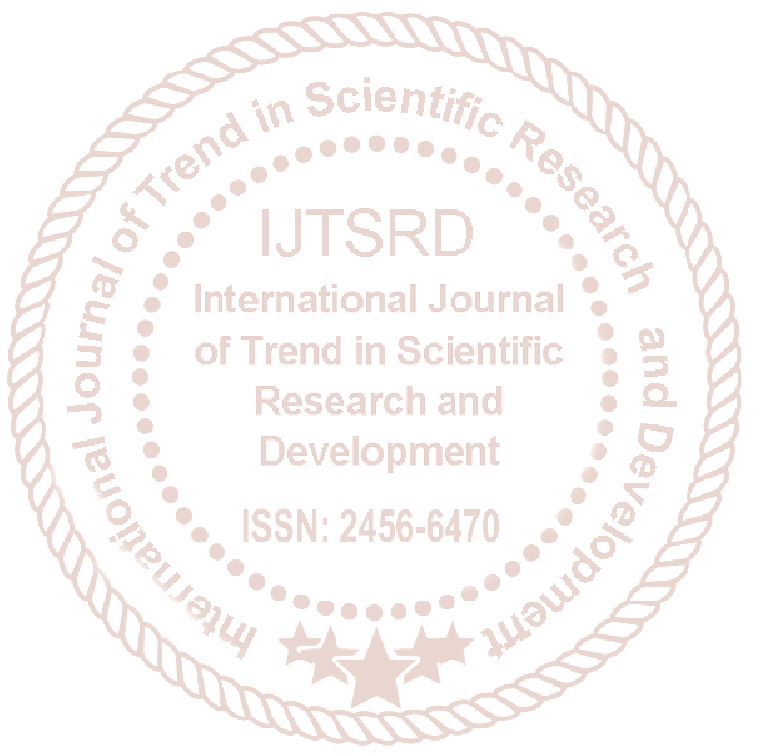

